\title{
Workplace Friendship, Helping Behavior, and Turnover Intention: The Meditating Effect of Affective Commitment
}

\author{
Hsu Yu-Ping ${ }^{1}$, Peng Chun-Yang ${ }^{2}$, Chou Ming-Tao ${ }^{3}$, Yeh Chun-Tsen ${ }^{4}$ and \\ Zhang Qiong-yuan ${ }^{5}$
}

\begin{abstract}
The present study drew from the social identity theory to explore the workplace friendship and adopted the social support theory to examine the effects of workplace friendship on affective commitment, helping behavior, as well as turnover intention. Research subjects of this study were civil affairs workers in Tainan and Chiayi County, Taiwan. Random sampling was used to collect anonymous questionnaires. The results of structural equation modeling (SEM) demonstrated that workplace friendship had positive influences on affective commitment and helping behavior and a negative influence on turnover intention. Prior research offered little empirical evidence of affective commitment as a mediating mechanism linking the workplace friendship-helping behavior and workplace friendship-turnover intention relationships. The present study found that effective commitment played an important mediating role. Implications for practice were discussed, and directions for future research were provided.
\end{abstract}

Keywords: Workplace friendship, Affective commitment, Helping behavior, Turnover intention.

${ }^{1}$ Chang Jung Christian University. Department of Tourism, Food \& Beverage Management

2 Chang Jung Christian University. Department of Accounting and Information Systems.

${ }^{3}$ Chang Jung Christian University. Department of Aviation and Maritime Transportation

Management.

${ }^{4}$ Chang Jung Christian University. Department of Finance.

${ }^{5}$ Chang Jung Christian University. Department of Business Administration.

Article Info: Received: September 6, 2020. Revised: September 25, 2020.

Published online: September 30, 2020. 


\section{Introduction}

The social identity theory was proposed by social psychologists Henri Tajfel and John Turner in the 1970s. It depicts the cognitive process of individuals related to social identity as well as how social identity affects group and inter-group member behavior. Hogg and Terry (2000) pointed out that the social identity theory is concerned with how individuals understand themselves and others in a social environment. Individuals usually gain a part of their identity through their membership and interactions within the group and between groups. The present study predicts that an individual is more likely to establish friendships with their group members when the individual recognizes belongingness to a certain social group and, at the same time, awareness of the emotions and values brought by the group. Drawing on the social identity theory, this study intends to explore the concept of workplace friendship.

Workplace friendship is a social interpersonal relationship that develops naturally in a workplace. It not only involves friendly interaction and mutual understanding but also includes mutual trust, emotion, commitment, and the sharing of benefits and values (Dobel, 2001). Past research has shown that employees with good friends at work can increase mutual trust and respect and provide important information and feedback, thereby reducing employee insecurity and uncertainty. The positive functions also include increase employee enthusiasm and positive attitudes (Hamilton, 2007; Jehn and Shah, 1997) and promotion of career development (Sias, Smith and Avdeyeva, 2003).

Workplace friendship exists not only in the dyadic relationship between leaders and members (Kram and Isabella, 1985; Sias et al., 2003; Tse, Dasborough and Ashkanasy, 2008) but also in cross-level or inter-group relationships (Berman, West and Richter, 2002). Compared with cross-level and inter-group friendships, employees in the same group interact more frequently, have more communication opportunities (Brehm, 1985), and share common values and goals (Dobel, 2001). Therefore, it seems easier for employees to build close friendships in the group. In view of these ideas, this research mainly focuses on the friendships among group members.

Past research indicated that social support is an important resource in an organization as it helps to obtain, preserve, protect, and maintain important resources (e.g., workplace friendships), assist individuals in suppressing stress, or make up for resource loss (Brummelhuis and Bakker, 2012; Hobfoll, 1989). Furthermore, the support given by important others (e.g., supervisors and colleagues) can help individuals increase their self-confidence and courage to deal with stress (Hobfoll, 1989). Building on the rationale of social support theory, this study regards workplace friendship as a form of social support while attempting to examine the effects of workplace friendship on employee affective commitment, helping behavior, as well as turnover intention. Prior research offered little empirical evidence of affective commitment as a mediating mechanism linking the workplace friendship-helping behavior and workplace friendship-turnover 
intention relationships. Thus, the present study has considered affective commitment as a potential mediator and will provide practical implications for organizations in accordance with the empirical results.

\section{Literature Review and Hypotheses}

\subsection{Workplace friendship}

A good social relationship is the main source of happiness and health (Argyle, 1987). People often turn to others for emotional support when they feel tense or distressed. A workplace can be considered a good avenue where people can meet each other and pursue common interests. It provides opportunities for employees to share experience and help solve personal or job-related problems (Sias and Cahill, 1998). Andrews, Kacmar, Blakely and Bucklew (2008) indicated that friendly colleagues in the organization will strengthen the emotional closeness of employees. It is believed that workplace friendships provide many positive contributions, including mutual support and sharing of information (Kram and Isabella, 1985), which can help reduce employee work stress and thus improve the quality of work and productivity (Berman and West, 1998). In addition, workplace friendships can also enhance organizational commitment (Nielsen, Jex and Adams, 2000). These benefits gave managers reasons to gradually value workplace friendships (Berman et al., 2002).

According to Fehr (1996: 20), friendship is "a voluntary, personal relationship typically providing intimacy and assistance". The definition of workplace friendship is different from the general type of friendship; as the name implies, the focus of workplace friendship is the friendship that occurs in the workplace (Song, 2005). Workplace friendships are a phenomenon, not just behaviors among people in an organization that are conducted in a friendly manner. There should be "trust, liking, and shared interests or values" rather than being only mutual acquaintances (Berman et al., 2002, p. 218).

Past research has shown that friendships in the workplace affect personal and organizational outcomes (Gibbons and Olk, 2003; Lincoln and Miller, 1979; Riordan and Griffith, 1995). In particular, various researchers have investigated the positive influence of workplace friendships on stress relief, creativity, motivation, job involvement, job satisfaction, organizational commitment, and turnover (Gibbons and Olk, 2003; Kram and Isabella, 1985; Morrison, 2004; Riordan and Griffith, 1995).

Building on the social identity theory and social support theory, the present study will specifically focus on workplace friendship, affective commitment, helping behavior, and turnover intention and attempt to examine their relationships.

\subsubsection{Helping behavior}

Helping behavior, prosocial behavior, and altruistic behavior are similar terms that are often used interchangeably by psychologists (Krebs, 1970; Staub, 1979). Helping behavior is regarded as an important element of organizational citizenship 
behavior by many scholars studying in this field (Motowidlo, Borman and Schmit, 1997; Organ, 1990a; Williams and Anderson, 1991). It refers to the behavior of voluntarily assisting other members of the organization to perform related tasks (Anderson and Williams, 1996; Van Dyne and LePine, 1998). This type of behavior can make an organization functions smoothly and has a positive effect on organizational performance (Anderson and Williams, 1996; George, 1991; Van Dyne, Cummings and Parks, 1995).

\subsubsection{Turnover intention}

Employees are the human assets of an organization. When they start feeling unhappy with the organization that exhibits an unfriendly work environment and an overly stressed workplace atmosphere, they are likely to quit. Employee turnover behavior has a negative impact on the organizational climate and may even trigger the leaving intentions of other internal employees. Therefore, organizations are working to find effective ways to reduce employee turnover.

Turnover intention means that employees have a tendency to leave their original positions after working in the organization for a period of time. According to Caplan and Jones (1975), the intent to leave refers to the strength of an individual's desire to leave his job and find another job opportunity. Employees might consider the thought to leave the organization, search for job opportunities, and evaluate and compare other job opportunities once job dissatisfaction happens (Miller, Katerberg and Hulin, 1979; Mobley, 1977). Jaffrey, Charles, and Rajan (1989) pointed out that the turnover intention is the most important cognitive precursor of employee turnover, so it is the most predictive of turnover behavior. Kaur, Mohindru and Pankaj (2013) provided similar perspectives, stating that turnover intention refers to an employee's intent to change his job or voluntarily withdraw from the organization. An employee's actual turnover likely occurs when their leaving intentions increase.

\subsubsection{Workplace friendship and helping behavior}

Employee interaction is not limited to work roles; sometimes, it transcends them (Mao, 2006; Sias et al., 2003), indicating that when employees form good bonds, interaction with each other is not limited to work needs but may even exceed work requirements. Previous research indicated that friendships in the working environment also consist of the element of care (Winstead, Derlega, Montgomery and Pilkington, 1995). Employees will readily assist a colleague who needs aid, regardless of whether they receive feedback or not. Likewise, Hamilton (2007) stated that employees in good friendships tend to engage in helping behavior by providing colleagues with help, guidance, suggestions, feedback, recommendations, or information on various work-related matters.

To sum it up, when employees generally perceive good workplace friendships in the process of interaction, they will take the initiative to care for each other, help solve work-related and personal problems, and go beyond the responsibilities and 
obligations stipulated by the work role. In view of the above, the following hypothesis is developed:

H1: Workplace friendship has a positive effect on helping behavior.

\subsubsection{Workplace friendship and turnover intention}

In social support theory, social support means that individuals obtain substantial and emotional help through interaction with others or groups (Hobfoll and Stokes, 1988). The types of social support can be divided into emotional support (i.e., empathy, care, consideration, and encouragement from others), substantial support (i.e., obtaining material, labor, and money from others), appraisal support (i.e., affirmation or feedback from others) as well as esteem support (individuals gain confidence and self-esteem with the help of important others after failure) (House, 1981). Workplace friendships have similar types of support for the workplace. It can provide personal emotional support or resources in a timely manner when employees feel stressed, conflicted, or distressed in the workplace. Workplace friendships can also ease work pressures, resolve conflicts, and break through predicaments, as well as reduce dissatisfaction with their work (House, 1981).

Prior research indicated that employees without social support are prone to depression, anxiety, neuroticism, and anti-social behavior, which would subsequently lead to absenteeism and turnover behavior. Workplace friendships can help reduce these negative phenomena (Berman et al., 2002) and help employees reduce work stress, dissatisfaction with work, and employee turnover (Kram and Isabella, 1985). Based on the concept of social support theory, this study assumes that the workplace friendships can decrease employee turnover intention and, hence, proposes the following hypothesis:

H2: Workplace friendship has a negative effect on turnover intention.

\subsection{The mediating role of affective commitment}

\subsubsection{Affective commitment}

According to Porter, Crampon and Smith (1976), affective commitment includes three elements: (1) an employee's firm belief in and acceptance of the organization's goals and values; (2) an employee's voluntary contributions to the organization; and (3) an employee's strong desire to be part of the organization. Mowday, Steers and Portor (1979) referred affective commitment to the emotional attachment of employees to the organization, enabling them to identify with the organization's goals and internalize the organization's values. In line with the researchers previously mentioned, Meyer and Allen (1991) also stated that affective 
commitment refers to employees' identification with, involvement in, and emotional attachment to their work group. Employees with strong affective commitment tend to stay in the organization because they are willing to do so.

\subsubsection{The effects of affective commitment on the relationships between workplace friendship and helping behavior}

Social identity is how individuals feel about themselves based on their group membership. Tajfel (1979) proposed that groups to which individuals belong (social class, family, sports team, etc.) are an important source of pride and self-esteem. Groups give individuals a sense of social identity, that is, a sense of belonging to the social world. The social identity theory (Tajfel and Turner, 1986) depicts that part of a person's self-concept comes from the group a person belongs. A person is not limited to his own personality; it also includes multiple identities that relate to the group he belongs. In different social contexts, a person's behavior may vary depending on the group they belong to, which may include the sports team they follow, their family, the country where their nationality is located, and the neighborhood where they live (Tajfel and Turner, 1986).

The present study used the social identity theory to delineate the relationships among workplace friendship, affective commitment, and helping behavior. Workplace friendship is a dynamic phenomenon (Bridge and Baxter, 1992) that naturally forms in the workplace. Building good friendship among colleagues can improve the working atmosphere, enhance the emotional connection between members, strengthen mutual trust and help, and share value, work experience, and joys at work (Berman et al., 2002; Blieszner and Adams, 1992). Employees more likely identify with their work group when they have strong emotional connections with their colleagues. The sense of care is embodied within workplace friendships. Naturally, colleagues would show concerns and give assistance to an employee who encounters difficulties (Mills and Clark, 1982; Schwartz, 1977). In view of the above, the following hypotheses are developed:

H3: Workplace friendship has a positive effect on affective commitment.

H4: Affective commitment significantly mediates the relationships between workplace friendship and helping behavior.

\subsubsection{The effects of affective commitment on the relationships between workplace Friendship and turnover intention}

Social support has been extensively studied in the literature on stress and social networks (Hall and Wellman, 1985; Viswesvaran, Sanchez and Fisher, 1999). It is believed that individuals may have a working social support network and a personal or non-working support network. Social support at work may come from organizations, direct supervisors, and colleagues. Prior studies showed that social support in workplace has a positive influence on work outcomes (such as job satisfaction) (Goff, Mount and Jamison, 1990; Savery, 1988). 
In addition to the impact of workplace friendships, employees' affective commitment to the work group may play an important mediating role in retaining talents and reducing employee turnover intentions. Previous studies have shown that individuals with close work friends exhibit lower levels of absenteeism and are less likely to leave the organization. This is because they have a sense of belonging and emotional attachment to their workplace friends who have accepted, understood, and helped them at work (Morrison, 2004; Sias and Cahill, 1998). These are valuable reasons from the perspective of business operations as these lessen employee turnover. Hence, this study draws on the social support theory and predicts that good friendships between colleagues help enhance employees' emotional commitment to their work group, and that once employees identify with their group goals and values emotionally, their tendency to leave will decrease accordingly. Thus, the following hypothesis is developed:

H5: Affective commitment significantly mediates the relationships between workplace friendship and turnover intention.

According to the hypotheses, the proposed model is shown in Figure 1.

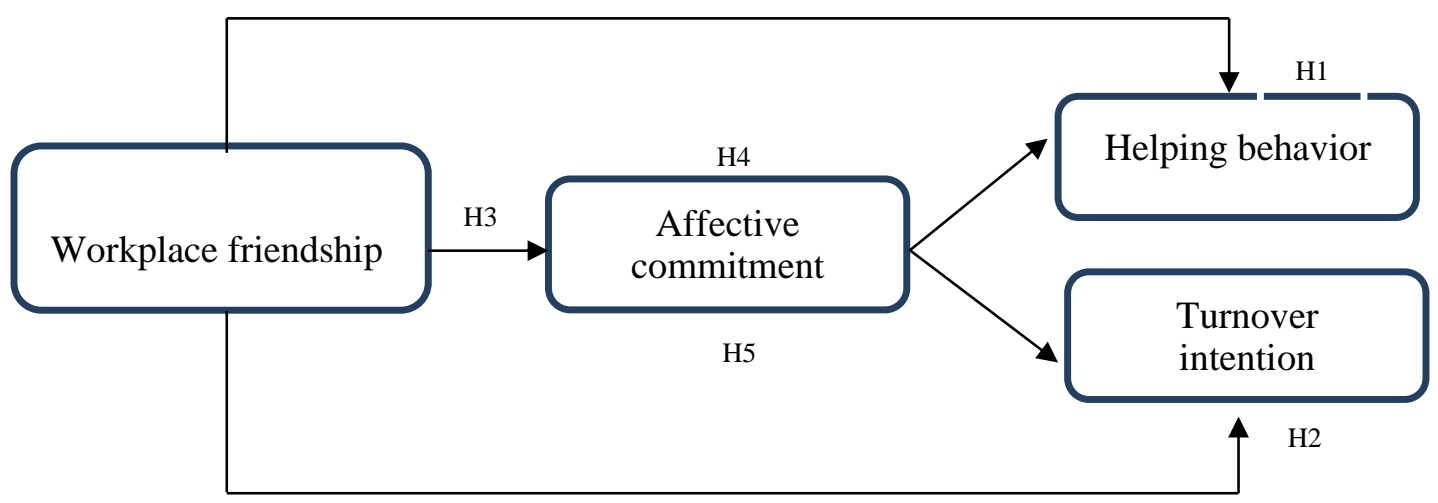

Figure 1: The Proposed Model

\section{Methods}

\subsection{Participants and procedures}

In order to verify the relationships between workplace friendship and work-related outcomes such as affective commitment, helping behavior, and turnover intention, this study took civil affairs workers in Tainan and Chiayi County, Taiwan as the research subjects and used random sampling to collect anonymous questionnaires. Workplace friendship was viewed as an independent variable, affective commitment as a mediating variable, and helping behavior and turnover intention as dependent variables. This research aims to test whether friendships in the workplace can lead to internal psychological changes in individuals. Since affective commitment and turnover intention are related to the individual's cognition and emotional state, the present study adopted self-rating method, that is, the question 
items were answered by the same respondents.

Nonetheless, the questionnaire filled out by the same respondent might cause common method variance (CMV) leading to an inflation of the correlation between the independent variable (i.e., workplace friendship) and the dependent variables (i.e., helping behavior and turnover intention). Hence, some of the question items were reversely designed and randomized in this study to avoid CMV and "reduce any potential ordering effects" (Neubert, Kacmar, Carlson, Chonko and Roberts, 2008). The present study also utilized Harman's one-factor test (Anderson and Bateman, 1997) to reduce the CMV. A principal components factor analysis on the question items yielded 4 factors with eigenvalues greater than 1.0, which accounted for $67.25 \%$ of the total variance. As the first factor $(26.81 \%)$ did not account for the majority of the variance, a substantial amount of CMV seemed to be absent (Podsakoff, MacKenzie, Lee and Podsakoff, 2003; Podsakoff and Organ, 1986). Hence, the problem of CMV was reduced greatly, indicating that there was no negative or positive affectivity behind the participants' response.

This study distributed 300 questionnaires to civil affairs offices in Tainan and Chiayi County. Of the 300 questionnaires, 252 were returned to the researcher. After deducting 67 incomplete questionnaires, 185 valid questionnaires were obtained. The effective questionnaire response rate was $61.67 \%$. In terms of demographics, $27.6 \%$ had tenures of less than 4 years, $21.6 \%$ had tenures from 9 to 12 years, and $35.1 \%$ had tenures of more than 13 years. As for education, $31.4 \%$ of the respondents graduated from high school/vocational high school, whereas $68.6 \%$ had college degrees or above.

\subsection{Measures}

Except for the demographic variables, all measures used response options ranging from 1 to 5 ( $1=$ strongly disagree, $5=$ strongly agree $)$. Items in the scales were averaged to create an overall mean for each variable. Higher values represent greater variable strengths.

Workplace friendship is built on mutual trust, commitment, emotional support, and shared information (Blieszner \& Adams, 1992). Workplace friendship was measured with a six-item scale developed by Nielsen et al. (2000). Sample items included the following: "I have formed strong friendships at work" and "Being able to see my coworkers is one reason why I look forward to my job." The Cronbach's alpha for this scale was 0.84 .

Affective commitment refers to employees' identification with, involvement in, and emotional attachment to their work group. Thus, employees with strong affective commitment remain members of their work group because they want to do so (Meyer and Allen, 1991). The eight-item affective commitment scale developed by Bishop and Scott (2000) was adapted. Sample items included the following: "I am proud to tell others that I am part of this work group" and "I find that my values and the work group's values are very similar." The Cronbach's alpha for this scale was 0.90 . 
Helping behavior refers to an employee's voluntary actions intended to assist colleagues with a problem or to relieve their distress. The four-item Altruism scale developed by Farh, Early, and Lin (1997) was used to measure helping behavior. Altruism is one of the dimensions of the organizational citizenship behavior scale and is sometimes referred to as helping behavior (Lin and Peng, 2010). One of the four items on the Altruism scale, "This employee will actively help recruits at my request", was inconsistent with the original purpose of the study, so it was not included. The meaning of the remaining three items was modified to better fit the purpose of this study. Sample items included the following: "I am happy to assist my colleagues in solving work difficulties." and "I am happy to share the work of my colleagues when necessary." The Cronbach's alpha for this scale was 0.62.

Turnover intention refers to an individual's state of mind before the occurrence of actual leaving behavior. Turnover intention mainly measures the subjective feelings of the organizational members, rather than actual behavior. It reflects the strength of an individual's desire to leave his present job and find another job opportunity (Caplan and Jones, 1975). Turnover intention was measured using a four-item scale developed by Kelloway, Gottlieb and Barham (1999). Sample items included the following: "I am thinking about leaving this organization." and "I am planning to look for a new job." The Cronbach's alpha for this scale was 0.89 .

\section{Main Results}

\subsection{Measurement model analysis}

This study uses confirmatory factor analysis (CFA) as the measurement model for examining the relationships between measurement variables and potential variables. Given that the discriminant index of the goodness of fit between model and observation data cannot rely on one single criterion, this study takes the recommendations of Hair, Black, Babin and Anderson (2010), who suggest that a proper goodness of fit shall consider "preliminary fit criteria", "overall model fit", and "fit of internal structural of model".

\subsubsection{Preliminary fit criteria}

In this study, all error variances of the measurement indices are positive numbers and reach the significance level. None of the error variances exceed standard error. As one of the measurement indices, factor loadings are all between 0.6 and 0.9 and reach significance level. According to principles raised by Bagozzi and Yi (1988), the preliminary fit criteria of this study are good in general.

\subsubsection{Overall model fit}

This study draws on the opinions of Bagozzi and Yi (1988), Hair et al. (2010), and Jöreskog and Sörbom (1984) by taking 11 of their indices to conduct the evaluation on overall model fitness; the indices are normed chi-square, $\chi^{2} / \mathrm{df}$, goodness of fit index (GFI), adjusted goodness of fit index (AGFI), standardized root mean square 
residual (SRMR), root mean square error of approximation (RMSEA), normed fit index (NFI), Tucker-Lewis index (TLI), incremental fit index (IFI), comparative fit index (CFI), parsimony comparative fit index (PCFI), and parsimony normed fit index (PNFI). Table 1 lists the overall model fit indices for this study's measurement model; the results are as follows: $\chi^{2} / \mathrm{df}=1.06$, GFI $=0.92$, AGFI $=$ 0.89 (this value is very close to 0.9 although it is smaller than 0.9 ), $\mathrm{SRMR}=0.05$, RMSEA $=0.02, \mathrm{NFI}=0.92, \mathrm{TLI}=0.99, \mathrm{IFI}=0.99, \mathrm{CFI}=0.99, \mathrm{PCFI}=0.79$, and PNFI $=0.73$. The analysis results show that the overall model fit indices for measurement model fitness for this study's measurement model is good.

Table 1: Overall model fit indices for measurement model

\begin{tabular}{|c|c|c|c|c|c|c|c|c|c|c|c|}
\hline $\begin{array}{c}\text { Model } \\
\text { Fit } \\
\text { indicators }\end{array}$ & $\chi \mathbf{2}$ /df & GFI & AGFI & SRMR & RMSEA & NFI & TLI & IFI & CFI & PCFI & PNFI \\
\hline Fit results & 1.1 & 0.92 & 0.89 & 0.05 & 0.02 & 0.92 & 0.99 & 0.99 & 0.99 & 0.79 & 0.73 \\
\hline $\begin{array}{c}\text { Cut-off } \\
\text { for good } \\
\text { fit }\end{array}$ & $1-3$ & $\geqq 0.90$ & $\geqq 0.90$ & $\leqq 0.05$ & $\leqq 0.08$ & $\geqq 0.90$ & $\geqq 0.90$ & $\geqq 0.90$ & $\geqq 0.90$ & $>0.50$ & $>0.50$ \\
\hline
\end{tabular}

Notes: $\chi 2 / d$ frepresents Normed Chi-square; GFI represents Goodness of Fit Index; AGFI represents Adjusted Goodness of Fit; SRMR represents Standardized Root Mean Square Residual; RMSEA represents Root Mean Square Error of Approximation; NFI represents Normed Fit Index; TLI represents Tucker-Lewis Index; IFI represents Incremental Fit Index; CFI represents Comparative Fit Index; PCFI represents Parsimonious Comparative-fit-index; PNFI represents Parsimonious Normed Fit Index.

\subsubsection{Fit of internal structure of model}

\subsubsection{Composite reliability and convergent validity}

This study adopts composite reliability (CR) and average variance explained (AVE) as the indices for examining the reliability and validity of potential variables. Using CFA, this study found that the factor loadings of potential variables all reach the significance level of parameters, and most of the factor loadings are between 0.6 and 0.9. As seen in Table 2, the CR of all variables is between 0.62 and 0.92 ; this agrees with the point raised by Bagozzi and Yi (1988), i.e., this index shall be equal to or larger than 0.6. Thus, all potential variables have good CR, which is indicative of the high correlation between this study's observation variables and potential variables. Regarding AVE, when it gets larger, its related measurement error is smaller; AVE's ideal value is at least above 0.5. Fornell and Larcker (1981) stated than an AVE smaller than 0.5 and a CR larger than 0.6 suggest potential variables with good convergent validity (CV). In Table 2, AVE of potential variables are all between 0.35 and 0.68 , whereas all CR are above 0.6. Thus, all potential variables of this study have good CV. 
Table 2: Composite reliability and average variance explained

\begin{tabular}{|c|c|c|}
\hline Potential variables & $\begin{array}{c}\text { Composite } \\
\text { Reliability }\end{array}$ & $\begin{array}{c}\text { Average Variance } \\
\text { Explained }\end{array}$ \\
\hline Workplace friendship & 0.85 & 0.53 \\
\hline Affective commitment & 0.92 & 0.54 \\
\hline Helping behavior & 0.62 & 0.35 \\
\hline Turnover intention & 0.89 & 0.68 \\
\hline
\end{tabular}

\subsubsection{Discriminant validity}

If there is no complete correlation between two potential variables, then it is said that those two potential variables are discriminable. Ping (2004) suggested that if the correlation coefficient regarding two potential variables is $>|0.7|$, then the estimation method of confidence interval (C.I.) shall be adopted to verify discriminant validity (DV). Hancock and Nevitt (1999) suggested a minimum number of bootstrapping, that is, 250 times, when estimating path coefficient. If the C.I. of this bootstrap regarding the correlation coefficient does not include 1, then there is DV between potential variables (Torkzadeh, Koufteros and Pflughoeft, 2003). This study employs the bootstrap method and re-samples 2000 times to compute the bootstrap bias-corrected (BC) 95\% C.I. of the correlation coefficient between potential variables. Table 3 lists all the correlation coefficients between potential variables and their BC 95\% C.I., among which the correlation coefficient between Workplace Friendship and Affective Commitment is 0.72 (BC 95\% C.I.: $[0.60,0.81])$; the correlation coefficient between Workplace Friendship and Helping Behavior is 0.50 (BC 95\% C.I.: [0.32, 0.67]); the correlation coefficient between Workplace Friendship and Turnover Intention is -0.19 (BC 95\% C.I.: $[-0.35,-0.01])$; the correlation coefficient between Affective Commitment and Helping Behavior is 0.53 (BC 95\% C.I.: [0.36, 0.67]); and the correlation coefficient between Affective Commitment and Turnover Intention is -0.27 (BC 95\% C.I.: $[-0.43,-0.12])$. The correlation coefficient between Helping Behavior and Turnover Intention is -0.24 (BC 95\% C.I.: $[-0.43,-0.05]$ ). Findings show that none of the bootstrap BC 95\% C.I. of the correlation coefficients of the potential variables has 1 , which is indicative of the DV of all potential variables. 
Table 3: Potential variables correlation matrix

\begin{tabular}{|c|c|c|c|c|}
\hline $\begin{array}{c}\text { Potential } \\
\text { variables }\end{array}$ & $\begin{array}{c}\text { Workplace } \\
\text { friendship }\end{array}$ & $\begin{array}{c}\text { Affective } \\
\text { commitment }\end{array}$ & $\begin{array}{c}\text { Helping } \\
\text { behavior }\end{array}$ & $\begin{array}{c}\text { Turnover } \\
\text { intention }\end{array}$ \\
\hline Workplace & 1 & 1 & & \\
\hline $\begin{array}{c}\text { Affective } \\
\text { commitment }\end{array}$ & $0.72^{* *}[0.60,0.81]$ & & 1 & 1 \\
\hline $\begin{array}{c}\text { Helping } \\
\text { behavior }\end{array}$ & $0.50^{* *}[0.32,0.67]$ & $0.53^{* *}[0.36,0.67]$ & & \\
\hline $\begin{array}{c}\text { Turnover } \\
\text { intention }\end{array}$ & $-0.19^{*}[-0.35,-0.01]$ & $-0.27 * *[-0.43,-0.12]$ & $-0.24 *[-0.43,-0.05]$ & 1 \\
\hline
\end{tabular}

Notes: $* p<0.05 ; * * p<0.01 ;[, \quad]$ represents BC 95\% C.I.

\subsection{Structural model analysis}

This study used the statistics software AMOS 25.0 for Windows to further understand the cause and effect of the overall model and the goodness of fit of the research model; conduct structural equation modeling (SEM) analysis; discuss the cause and effect of potential variables, such as workplace friendship, affective commitment, helping behavior, and turnover intention; and further verify the hypotheses.

\subsubsection{Assessment for SEM}

SEM can be divided into two sections. The first section refers to the "measurement model", which utilizes CFA to discuss the relationship between measurement variables and potential variables. The second section is the "structural model," which analyzes the relationship between potential variables in theory (Hoyle and Panter, 1995). The SEM and CFA assessment approaches are similar; results of preliminary fit criteria and fit of internal structural model of the research model after conducting SEM analysis are the same as those of the former analysis. Moreover, this study considers the opinions of Bagozzi and Yi (1988), Hair et al. (2010), and Jöreskog and Sörbom (1984) and selects 11 indices to conduct the assessment on overall model fit. Table 4 shows the overall model fit indices as follows: $\chi^{2} / \mathrm{df}=$ 1.04 , GFI $=0.92$, AGFI $=0.89$ (this value is less than 0.9 but very close to 0.9 ), SRMR $=0.04$, RMSEA $=0.01, \mathrm{NFI}=0.92, \mathrm{TLI}=0.99, \mathrm{IFI}=0.99, \mathrm{CFI}=0.99$, PCFI $=0.80$, and PNFI $=0.74$, suggesting a good overall model fit of the research model. These results validate the efficacy of the SEM for this research. 
Table 4: Overall model fit indices for SEM

\begin{tabular}{|c|c|c|c|c|c|c|c|c|c|c|c|}
\hline $\begin{array}{l}\text { Model fit } \\
\text { indicators }\end{array}$ & $\begin{array}{l}\boldsymbol{\chi} \mathbf{2} / \\
\text { df }\end{array}$ & GFI & AGFI & SRMR & RMSEA & NFI & TLI & IFI & CFI & PCFI & PNFI \\
\hline Fit results & 1.04 & 0.92 & 0.89 & .04 & 0.01 & 0.92 & 0.99 & 0.99 & 0.99 & 0.80 & 0.74 \\
\hline $\begin{array}{c}\text { Cut-off for } \\
\text { good fit }\end{array}$ & $1-3$ & $\geqq .90$ & $\geqq .90$ & $\leqq .05$ & $\leqq .08$ & $\geqq .90$ & $\geqq .90$ & $\geqq .90$ & $\geqq .90$ & $>.50$ & $>.50$ \\
\hline
\end{tabular}

Notes: $\chi 2 / d f$ represents Normed Chi-square; GFI represents Goodness of Fit Index; AGFI represents Adjusted Goodness of Fit; SRMR represents Standardized Root Mean Square Residual; RMSEA represents Root Mean Square Error of Approximation; NFI represents Normed Fit Index; TLI represents Tucker-Lewis Index; IFI represents Incremental Fit Index; CFI represents Comparative Fit Index; PCFI represents Parsimonious Comparative-fit-index; PNFI represents Parsimonious Normed Fit Index.

\subsubsection{Hypotheses testing}

This study conducts estimation and examination based on the influence of overall model structure on potential variables. Table 5 lists the standardized direct effect, indirect effect, and total effect between all potential variables. The standardized direct effect between potential variables is the $\beta$ value of the standardized regression coefficient. The significance of this $\beta$ value and its critical ratio (C.R.) are analyzed as follows: The path analysis of Workplace Friendship $\rightarrow$ Helping Behavior shows $\beta=0.31$, C.R. $=2.17$, suggesting that Workplace Friendship has a positive effect on Helping Behavior, supporting Hypothesis 1. The path analysis of Workplace Friendship $\rightarrow$ Turnover Intention shows $\beta=0.03$, C.R. $=0.28$, indicating that Workplace Friendship has no significant effects on Turnover Intention; hence, Hypothesis 2 is not supported. The path analysis of Workplace Friendship $\rightarrow$ Affective Commitment reveals $\beta=0.60$, C.R. $=7.03$, indicating that Workplace Friendship has a positive effect on Affective Commitment; hence, Hypothesis 3 is supported.

Regarding the examination of mediating effects, Preacher and Hayes (2008a) suggested employing a bootstrapping $\mathrm{BC}$ procedure to conduct the estimation of 95\% C.I., which suggests presence of an intermediate effect if it does not include 0 . This study employs the bootstrap method and re-samples 2000 times so as to estimate the BC 95\% C.I. of indirect effects. Table 5 shows a total effect of 0.50 for Workplace Friendship on Helping Behavior, with a direct effect for Workplace Friendship on Helping Behavior of the order of 0.31, and an indirect effect through Affective Commitment, the mediating variable, of $0.560 * 0.31=0.19$. Its BC $95 \%$ C.I. is $[0.04,0.33]$, which does not include 0 , indicating that there is a mediating effect on the relationship between Workplace Friendship and Helping Behavior; hence, Hypothesis 4 is supported. In addition, the total effect of Workplace Friendship on Turnover Intention is -0.15 , the direct effect of Workplace Friendship on Turnover Intention is 0.03, and the indirect effect through Affective Commitment, the mediating variable, is $0.60 *(-0.3)=-0.18$. Its BC $95 \%$ C.I. is 
$[-0.32,-0.07]$, which does not include 0 , indicating that there is a mediating effect on the relationship between Workplace Friendship and Turnover Intention. Thus, Hypothesis 5 is supported.

Table 5: Summary of standardized direct, indirect and total effect

\begin{tabular}{|l|c|c|c|c|}
\hline $\begin{array}{c}\text { Potential independent } \\
\text { variables }\end{array}$ & $\begin{array}{c}\text { Potential } \\
\text { dependent } \\
\text { variables }\end{array}$ & Direct effect & Indirect effect & Total effect \\
\hline Workplace friendship & Helping behavior & $\begin{array}{c}0.31^{*} \\
{[0.08,0.55]}\end{array}$ & $\begin{array}{c}0.19^{*} \\
{[0.041,0.33]}\end{array}$ & $\begin{array}{c}0.50^{*} \\
{[0.33,0.69]}\end{array}$ \\
\hline Workplace friendship & $\begin{array}{c}\text { Turnover } \\
\text { intention }\end{array}$ & $\begin{array}{c}0.03 \\
{[-016,0.21]}\end{array}$ & $\begin{array}{c}-0.18^{* *} \\
{[-0.32,-0.07]}\end{array}$ & $\begin{array}{c}-0.15^{* *} \\
{[-0.29,-} \\
0.01]\end{array}$ \\
\hline Workplace friendship & Affective & $0.60^{* *}$ & None & $0.60^{* *}$ \\
& commitment & {$[0.48,0.69]$} & & {$[0.48,0.69]$} \\
\hline Affective commitment & Helping behavior & $0.31^{*}$ & None & $\begin{array}{c}0.31^{*} \\
{[0.057,}\end{array}$ \\
& & $0.512]$ & & {$[0.06,0.51]$} \\
\hline Affective commitment & Turnover & $-0.30^{* *}$ & None & $-0.30^{* *}$ \\
& intention & {$[-0.50,-0.12]$} & & $0.50,-$ \\
& & & & $0.12]$ \\
\hline
\end{tabular}

Notes: $* p<0.05 ; * * p<0.01$; Total effect= Direct effect + Indirect effect; [ , ] represents BC $95 \%$ C.I.

\section{Discussion}

No known research in the existing literature has specifically examined helping behavior as the potential behavioral outcome of workplace friendship. As previously stated, the interaction among employees is not only limited to work roles, it goes beyond that (Mao, 2006; Sias et al., 2003). That is to say, when employees form strong bonds, mutual interaction is not limited to work needs but even exceeds work requirements. In addition, workplace friendship has the characteristics of actively caring for friends (Winstead, Derlega, Montgomery and Pilkington, 1995); they tend to help each other, often unconditionally, especially when one extremely needs assistance. The above studies provide theoretical support for our findings, that is, friendship in the workplace indeed have a positive influence on helping behavior. When there is a good friendship atmosphere within a work group, employees will exhibit helpful behaviors that are beneficial to the group and the organization. 
With regard to the relationship between workplace friendship and turnover intention, past research showed that employees that lack social support are prone to depression, anxiety, neuroticism, and anti-social behavior, which subsequently lead to absenteeism and turnover behavior. Nevertheless, workplace friendships can ease these negative phenomena (Berman et al., 2002) and help employees reduce work stress, dissatisfaction with work, and turnover (Kram and Isabella, 1985). Although our research result reveals that the workplace friendship-turnover intention relationship was not statistically significant, the negative relationship between the two variables was in line with prior research.

Moreover, relatively few studies have explored the group affective commitment as the mediating variable of workplace friendship and work-related outcomes (particularly helping behavior and turnover intention). Our study results confirm Hypotheses 3, 4, and 5 and reveal that workplace friendship had a positive effect on affective commitment, which in turn significantly influenced helping behavior and turnover intention. In other words, affective commitment had played an important mediating role in both workplace friendship-helping behavior and workplace friendship-turnover intention relationships. According to social identity theory, it is easier for in-group members with similarities to build friendships as compared with members of outside groups (Tajfel and Turner, 1986). Peer support comes from friendship ( $\mathrm{Lu}, 1999)$; in a work group, if there are friendly colleagues giving mutual support, the group not only fills with a positive working atmosphere and happiness but can also enhance the members' affective commitment toward the group. Based on social support theory and group-person fit, when members emotionally identify with the group and share common values and goals, they are likely to show mutual support, cooperation, and altruistic behavior; and their intention to leave may also decrease.

\section{Practical Implications, Directions for Future Research, and Conclusion}

\subsection{Practical implications}

Berman et al. (2002) emphasized that the formal remuneration of the organization cannot replace social interaction. Employees who lack social interaction would develop increase anxiety, disappointment, and neuroticism, which consequently lead to absenteeism, low morale and work motivation, and turnover behavior. Hence, workplace friendship is an important social resource in establishing good interpersonal relationships among group members, making work more attractive and making employees willing to stay in the group (Nielsen et al., 2000). In a group, mutual support and information sharing can help reduce the work pressure of employees, provide more communication, cooperation, vitality, as well as improve work quality. Employees may also feel comfortable with their group members and hence, reduce feelings of insecurity and uncertainty. In addition, employees may show empathies and help colleagues solve problems about work-related issues 
(Hamilton, 2007). In view of the above positive benefits of workplace friendship, the present study recommends that managers should value workplace friendship and actively encourage its development in the group and organization.

\subsection{Directions for future research}

This study primarily focused on the impacts of workplace friendship on affective commitment, help behavior, and turnover intention of civil affairs workers in Tainan and Chiayi County, Taiwan. Therefore, the research results cannot be extended to other industries. Future researchers may explore the same variables in the service industry, then analyze the results and compare differences. In addition, the study adopted the self-rating method, that is, the same respondents (i.e., civil affairs workers) answered all question items. Future studies should invite direct supervisors to rate the helping behavior of their subordinates to decrease the potential common method bias.

Past research has shown that members of a highly cohesive group have positive feelings for each other and are more inclined to participate and stay with the group (Lata and Kamalanabhan, 2005; Lott and Lott, 1965). Since there is no known research that explicitly considers group cohesion as a potential mediating variable between workplace friendships and work-related outcomes, it may be worth exploring in future research. In addition, job burnouts are common in employees working in a high-pressure environment. It is a long-term state of mental, emotional, or physical exhaustion and also involves a reduced sense of accomplishment and loss of personal identity. Workplace friendships may be a positive contextual factor in reducing job burnout and, hence, is worth future study.

\subsection{Conclusion}

Overall, the empirical results provide support to our original assumptions and demonstrate that workplace friendship had positive influences on affective commitment and helping behavior, and a negative influence on turnover intention. The present study also found that affective commitment significantly mediated the workplace friendship-helping behavior relationship as well as the workplace friendship-turnover behavior relationship, proving that affective commitment is a mediator. The results of this research have expanded the existing literature on workplace friendships. Managers or group leaders should promote the formation of friendships between employees and make friendship an important social network within the organization. 


\section{References}

[1] Andersson, L.M. and Bateman, T.S. (1997). Cynicism in the workplace: Some causes and effects. Journal of Organizational Behavior. 18(5), pp.449-469.

[2] Anderson, S.E. and Williams, L.J. (1996). Interpersonal, job, and individual factors related to helping processes at work. Journal of Applied Psychology. 81(3), pp.282-296.

[3] Andrews, M.C., Kacmar, K.M., Blakely, G.L. and Bucklew, N.S. (2008).

[4] Group cohesion as an enhancement to the justice - Affective commitment relationship. Group \& Organization Management. 33(6), pp.736-755.

[5] Argyle, M. (1987). The Psychology of Happiness. London: Methuen.

[6] Bagozzi, R. and Yi, Y. (1988). On the evaluation of structural equation models. Journal of the Academy of Marketing Sciences. 16, pp.74-94.

[7] Berman, E.M. and West, J.P. (1998). Responsible risk-taking. Public Administration Review. 58(4), pp.346-352.

[8] Berman, E.M., West, J.P. and Richter, M.N. (2002). Workplace relations: Friendship patterns and consequences (According to managers). Public Administration Reviews. 62, pp.217-230.

[9] Bishop, J.W. and Scott, K.D. (2000). Organizational and team commitment in a team environment. Journal of Applied Psychology. 85, pp.439-450.

[10] Blieszner, R. and Adams, R.G. (1992). Sage series on close relationships. Adult Friendship. Sage Publications, Inc.

[11] Brehm, S.S. (1985). Intimate Relationships. Crown Publishing Group/Random House.

[12] Bridge, K. and Baxter, L.A. (1992). Blended relationships: Friends as work associates. Western Journal of Communication (Includes Communication Reports). 56, pp. 200-225.

[13] Brummelhuis, L.L.T. and Bakker, A.B. (2012). A resource perspective on the work-home interface: The work-home resources model. American Psychologist. 67(7), pp.545-56.

[14] Caplan, R. D. and Jones, K. W. (1975). Effects of work load, role ambiguity, and type A personality on anxiety, depression, and heart rate. Journal of Applied Psychology. 60(6), pp.713-719.

[15] Dobel, J. P. (2001). Can public leaders have friends? Public Integrity, 3(2), pp.145-158.

[16] Farh, J.L., Earley, P.C. and Lin, S.C. (1997). Impetus for action: A cultural analysis of justice and organizational citizenship behavior in Chinese society. Administrative Science Quarterly. 42, pp.421-444.

[17] Fehr, B. (1996). Sage series on close relationships. Friendship Processes. Sage Publications, Inc.

[18] Fornell, C. and Larcker, D. F. (1981). Evaluating structural equation models with unobservable variables and measurement error. Journal of Marketing Research. 18(1), pp.39-50. 
[19] George, J.M. (1991). State or trait: Effects of positive mood on prosocial behaviors at work. Journal of Applied Psychology. 76(2), pp.299-307.

[20] Gibbons, D. and Olk, P.M. (2003). Individual and structural origins of friendship and social position among professionals. Journal of Personality and Social Psychology. 84(2), pp.340-351.

[21] Goff, S.J., Mount, M.K. and Jamison, R.L. (1990). Employer supported child care, work/family conflict, and absenteeism: A field study. Personnel Psychology. 43, pp.793-809.

[22] Hair, J.F., Black, W.C., Babin, B.J. and Anderson, R.E. (2010). Multivariate Data Analysis. New York: Pearson.

[23] Hall, A. and Wellman, B. (1985). Social networks and social support. In S. Cohen \& S. L. Syme (Eds.), Social Support and Health. Academic Press, pp.23-41.

[24] Hamilton, E.A. (2007). Firm Friendship: Examining Functions and Outcomes of Workplace Friendship among Law Firm Associates. Unpublished Doctoral Dissertation. Boston, MA: Boston College.

[25] Hancock, G.R. and Nevitt, J. (1999). Bootstrapping and the identification of exogenous latent variables within structural equation models. Structural Equation Modeling. 6, pp.394-399.

[26] Hobfoll, S.E. (1989). Conservation of resources: A new attempt at conceptualizing stress. American Psychologist. 44(3), pp.513-524.

[27] Hobfoll, S.E. and Stokes, J.P. (1988). The process and mechanics of social support. In S. Duck, D.F., Hay, S.E. Hobfoll, W. Ickes \& B.M. Montgomery (Eds.), Handbook of Personal Relationships: Theory, Research and Interventions. John Wiley \& Sons, pp.497-517.

[28] Hogg, M.A. and Terry, D.J. (2000). Social identity and self-categorization processes in organizational contexts. The Academy of Management Review. 25, pp.121-140.

[29] House, J.S. (1981). Work Stress and Social Support. Reading, Mass: AddisonWesley.

[30] Hoyle, R. H. and Panter, A. T. (1995). Writing about structural equation models. In R. H. Hoyle (Ed.), Structural Equation Modeling: Concepts, Issues, and Applications. Thousand Oaks, CA, US: Sage Publications, Inc., pp. 158176.

[31] Jaffrey, K.S., Charles, M.F. and Rajan, V. (1989). Exploring salesperson turnover: A casual model. Journal of Business Research. 18(1), pp.305-308.

[32] Jehn, K.A. and Shah, P.P. (1997). Interpersonal relationships and task performance: An examination of mediation processes in friendship and acquaintance groups. Journal of Personality and Social Psychology. 72(4), pp.775-790.

[33] Joreskog, K.G. and Sorbom, D. (1984). Advances in Factor Analysis and Structural Equation Models. Lanham: Rowman \& Littlefield Publishers. 
[34] Kaur, B. and Mohindru, Pankaj. (2013). Antecedents of turnover intentions: A literature review. Global Journal of Management and Business Studies. 3(10), pp.1219-1230.

[35] Kelloway, E.K., Gottlieb, B.H. and Barham, L. (1999). The source, nature, and direction of work and family conflict: A longitudinal investigation. Journal of Occupational Health Psychology. 4(4), pp.337-346.

[36] Kram, K.E. and Isabella, L.A. (1985). Mentoring alternatives: The role of peer relationships in career development. Academy of Management Journal. 28(1), pp.110-132.

[37] Krebs, D. (1975). Empathy and altruism. Journal of Personality and Social Psychology. 32(6), pp.1134-1146.

[38] Lata, D. and Kamalanabhan, T.J. (2005). Unearthed: The other side of group cohesiveness. Journal of Social Sciences. 10(3), pp.185-190.

[39] Lin, C.C. and Peng, T.K. (2010). From organizational citizenship behaviour to team performance: The mediation of group cohesion and collective efficacy. Management and Organization Review. 6, pp.55-75.

[40] Lincoln, J.R. and Miller, J. (1979). Work and friendship ties in organizations: A comparative analysis of relation networks. Administrative Science Quarterly. 24(2), pp. 181-199.

[41] Lott, A.J. and Lott, B.E. (1965). Group cohesiveness as interpersonal attraction: A review of relationships with antecedent and consequent variables. Psychological Bulletin. 64, pp.259-309.

[42] Lu, L. (1999). Work motivation, job stress and employees' well-being. Journal of applied Management. 8(1), pp.61-73.

[43] Mao, H.Y. (2006). The relationship between organizational level and workplace friendship. International Journal of Human Resource Management. 17, pp.1819-1833.

[44] Meyer, J.P. and Allen, N.J. (1991). A three-component conceptualization of organizational commitment. Human Resource Management Review. 1, pp.6189.

[45] Miller, H.E., Katerberg, R. and Hulin, C.L. (1979). Evaluation of the Mobley, Horner, and Hollingsworth model of employee turnover. Journal of Applied Psychology. 64(5), pp.509-517.

[46] Mills, J. and Clark, M.S. (1982). Communal and exchange relationships. In L. Wheeler (Ed.), Annual Review of Personality and Social Psychology. Beverly Hills, CA: Sage, pp.121-144.

[47] Mobley, W.H. (1977). Intermediate linkages in the relationship between job satisfaction and employee turnover. Journal of Applied Psychology. 62(2), pp.237-240.

[48] Morrison, R. (2004). Informal relationships in the workplace: Associations with job satisfaction, organisational commitment and turnover intentions. New Zealand Journal of Psychology. 33(3), pp.114-128. 
[49] Motowidlo, S.J., Borman, W.C. and Schmit, M.J. (1997). A theory of individual differences in task and contextual performance. Human Performance. 10(2), pp.71-83.

[50] Mowday, R.T., Steers, R.M. and Porter, L.W. (1979). The measurement of organizational commitment. Journal of Vocational Behavior. 14(2), pp.224247.

[51] Neubert, M.J., Kacmar, K.M., Carlson, D.S., Chonko, L.B. and Roberts, J.A. (2008). Regulatory focus as a mediator of the influence of initiating structure and servant leadership on employee behavior. Journal of Applied Psychology. 93(6), pp.1220-1233.

[52] Nielsen, I.K., Jex, S.M. and Adams, G.A. (2000). Development and validation of scores on a two-dimensional workplace friendship scale. Educational and Psychological Measurement. 60(4), pp.628-643.

[53] Organ, D.W. (1990a). The motivational basis of organizational citizenship behavior. In B.M. Staw \& L.L. Cummings (Eds.), Research in Organizational Behavior. Greenwich, CT: JAI Press, pp.43-72.

[54] Ping, R. (2004). On assuring valid measures for theoretical models using survey data. Journal of Business Research. 57(2), pp.125-141.

[55] Podsakoff, P.M., MacKenzie, S.B., Lee, J.Y. and Podsakoff, N.P. (2003). Common method biases in behavioral research: A critical review of the literature and recommended remedies. Journal of Applied Psychology. 88(5), pp.879-903.

[56] Podsakoff, P.M. and Organ, D.W. (1986). Self-reports in organizational research: Problems and prospects. Journal of Management. 12(4), pp.531-544.

[57] Porter, L.W., Crampon, W.J. and Smith, F.J. (1976). Organizational commitment and managerial turnover: A longitudinal study. Organizational Behavior \& Human Performance. 15(1), pp.87-98.

[58] Preacher, K.J. and Hayes, A.F. (2008a). Asymptotic and resampling strategies for assessing and comparing indirect effects in multiple mediator models. Behavior Research Methods. 40, pp. 879-891.

[59] Riordan, C.M. and Griffeth, R.W. (1995). The opportunity for friendliness in the workplace: An underexplored construct. Journal of Business \& Psychology. 10(2), pp.141-154.

[60] Savery, L.K. (1988). The influence of social support on the reaction of an employee. Journal of Managerial Psychology. 3(1), pp.27-31.

[61] Schwartz, S.H. (1977). Normative influence on altruism. In L. Berkowitz (Ed.), Advances in Experimental Social Psychology. New York: Academic Press, pp. 221-279.

[62] Sias, P.M. and Cahill, D.J. (1998). From coworkers to friends: The development of peer friendships in the workplace. Western Journal of Communication. 62(3), pp.273-299.

[63] Sias, P.M., Smith, G. and Avdeyeva, T. (2003). Sex and sex-composition differences and similarities in peer workplace friendship development. Communication Studies, 54, pp.322-340. 
[64] Song, S. (2005). Workplace Friendship and Its Impact on Employees' Positive Work Attitudes: A Comparative Study of Seoul City and New Jersey State Government Public Officials. Unpublished Doctoral Dissertation. Rutgers, The State University of New Jersey. Newark, NJ.

[65] Staub, E. (1979). Positive Social Behavior and Morality: Socialization and Development. New York: Academic Press.

[66] Tajfel, H. (1979). Individuals and groups in social psychology. British Journal of Social \& Clinical Psychology. 18(2), pp.183-190.

[67] Tajfel, H. and Turner, J.C. (1986). The social identity theory of intergroup behavior. In S. Worchel \& W.G. Austin (Eds.), Psychology of Intergroup Relation. Chicago: Hall Publishers, pp.7-24.

[68] Torkzadeh, G., Koufteros, X. and Pflughoeft, K. (2003). Confirmatory analysis of computer self-efficacy. Structural Equation Modeling. 10(2), pp.63-275.

[69] Tse, H.H.M., Dasborough, M.T. and Ashkanasy, N.M. (2008). A multi-level analysis of team climate and interpersonal exchange relationships at work. The Leadership Quarterly. 19(2), pp.195-211.

[70] Van Dyne, L., Cummings, L.L. and Parks, J.M. (1995). Extra-role behaviors: In pursuit of construct and definitional clarity. Research in Organizational Behavior. 17, pp.215-285.

[71] Van Dyne, L. and LePine, J.A. (1998). Helping and voice extra-role behaviors: Evidence of construct and predictive vlidity. Academy of Management Journal. 41(1), pp.108-119.

[72] Viswesvaran, C., Sanchez, J. I. and Fisher, J. (1999). The role of social support in the process of work stress: A meta-analysis. Journal of Vocational Behavior. 54(2), pp.314-334.

[73] Williams, L.J. and Anderson, S.E. (1991). Job satisfaction and organizational commitment as predictors of organizational citizenship and in-role behaviors. Journal of Management. 17(3), pp.601-617.

[74] Winstead, B.A., Derlega, V.J., Montgomery, M.J. and Pilkington, C. (1995). The quality of friendships at work and job satisfaction. Journal of Social and Personal Relationships. 12(2), pp.199-215. 